\title{
Equality prescribed? Contextual determinants of citizens' support for gender boardroom quotas across Europe
}

\author{
Katja Möhring ${ }^{1} \cdot$ Céline Teney $^{2}$
}

Published online: 4 November 2019

(c) The Author(s) 2019

\begin{abstract}
We provide the first cross-national comparative study of citizens' support for affirmative action policies in the economy using the example of gender quotas for company boards. In contrast to previous studies, we focus on the contextual level and analyse how factors related to political institutions and actors, and economic and social structure shape citizens' support and the gap in support between men and women. We apply multilevel regression analyses of Eurobarometer data for 27 European countries. Levels of support and gender gaps in support for boardroom quotas vary largely between countries. Contextual factors related to existing quota laws, gender equality in social and economic life, and public opinion towards state intervention are important determinants of cross-national variation. Our results point to an ambiguous relationship of support for gender quotas and actual gender equality in a country. Citizens' endorsement of quotas is low in countries with high levels of formal gender equality. Support is higher in countries where interventionist policies are widely accepted. Also, existing quota laws are positively related to citizens' support of boardroom quotas.
\end{abstract}

Keywords Gender equality $\cdot$ Discrimination $\cdot$ Political sociology $\cdot$ Multilevel analysis

Katja Möhring

moehring@uni-mannheim.de

Céline Teney

cteney@uni-goettingen.de

1 School of Social Sciences, University of Mannheim, Schloss, 68131 Mannheim, Germany

2 Institute of Sociology, University of Göttingen, Platz der Göttinger Sieben 3, 37073 Göttingen,

Germany 


\section{Introduction}

The contentious issue of gender equality in economic decision-making has taken hold in the European public sphere. The EU parliament put this topic in the foreground of the political arena with its non-binding resolution of July 2011, asserting that gender quotas for company boards should be implemented in all EU member states to raise the level of female board representation to $30 \%$ by 2015 and $40 \%$ by 2020 (Armstrong and Walby 2012; Pollack and Hafner-Burton 2000). However, large disparities in the proportion of female board members remain across Europe, ranging from $37.1 \%$ in France and only $8.8 \%$ in the Czech Republic in 2016 (European Commission 2016). Consequently, the issue of gender quotas in the economy has gained in salience and has led to the implementation of binding quotas for boards of large companies in several European countries. Besides, it has polarised actors in the public debates with opposition posed by populist parties and anti-gender movements all over Europe (Chaperon 2015; Kováts 2018).

While a large body of research exists on the general support of gender equality, our knowledge on the acceptance of affirmative action in the form of gender quotas for leading positions in business is limited, especially with respect to contextual determinants of citizens' attitudes towards such quotas. Over the last years, an increasing number of studies has focussed on the determinants and effects of political gender quotas for parliaments or party list positions (e.g. Barnes and Córdova 2016; Beauregard 2017; Kroeber et al. 2018; Ruedin 2012; Weeks 2018). These quotas have been implemented to ensure the representativeness in the democratic process. Gender quotas for board positions in companies clearly surpass regulations only guaranteeing equal treatment or representation as they imply a governmental intervention in entrepreneurial freedom (Elomäki 2017). The endorsement of affirmative action policies in the form of binding quotas therefore differs from more general attitudes towards gender equality as well as the acceptance of political quotas. This may explain why gender quotas in the economy are such a contested issue despite high and rising levels of gender equality in Europe. Support for gender equality and for affirmative action policies towards women represent two distinct attitudinal dimensions: one can endorse the principle of equality but reject the idea of state interventionism in this matter (Krysan 2000).

This article provides the first cross-national comparative study of citizens' support for gender quotas in the economy using the example of female representation on company boards. Previous research on political quotas shows that the context in which these are adopted is crucial for whether they in fact can lead to a reduction of gender inequality in political decision-making and participation (Beauregard 2017; Krook 2006). Therefore, an understanding of the determinants of citizens' support for boardroom quotas is pivotal to assess their potential for successfully enhancing equality in economic decision-making in top positions and beyond. Based on the 2011 Eurobarometer data, we investigate the role played by political institutions, economic and social structure, and social norms (i.e. 
what we referred to as 'contextual determinants') on citizens' support for gender boardroom quotas across EU countries. The attitudinal measure we analyse is the support for legislation introducing weak preferential treatment of women on company boards (hereafter 'support for gender quotas'), which is the supervisory board or the board of directors depending on country. Weak preferential treatment implies that "members of the target group are given preference over others if and only if their other qualifications are equivalent' (Harrison et al. 2006).

The support among citizens for such gender quotas varies largely between European countries in terms of the overall level of support as well as the gender gap in support, i.e. the difference in support levels between men and women (see Fig. 1). This is in line with previous research on political quotas also showing variation in both overall levels and gender gaps in support (Barnes and Córdova 2016). Therefore, we investigate not only the general relevance of contextual factors, but also the differentiated role that these factors might play among the target group (women) and the non-target group (men) of the policy. Accordingly, our research questions are, first, what country-level factors influence citizens' support for a gender quota; second, how do these factors impact (a) the overall level of support and (b) the gap in support between men and women.

The article is structured as follows: in the next section, we present a theoretical framework to analyse the impact that institutions, policies, gender equality

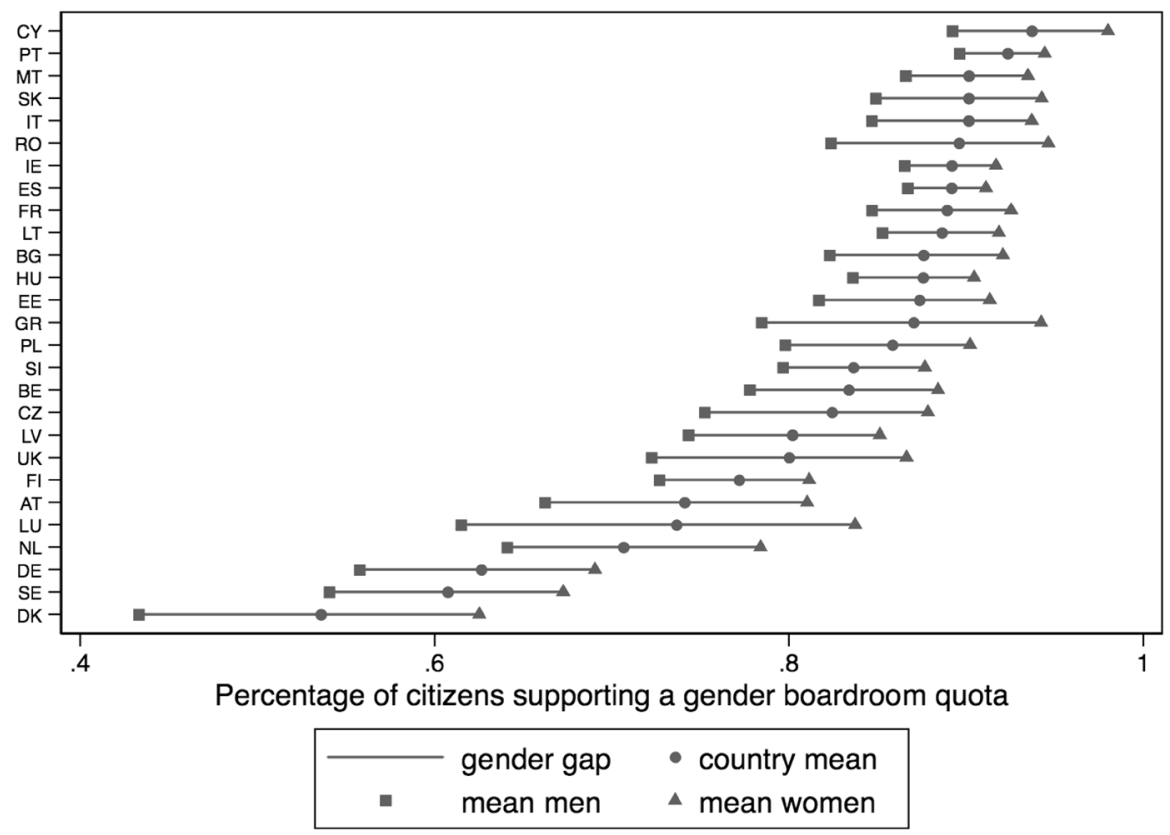

Fig. 1 Average level of support and gender gap in support for a gender quota for company boards by country. Notes: For this figure, we recoded the information from the variable support for a boardroom quota into two categories where 0 refers to 'totally or rather opposed' and 1 refers to 'totally or rather in favour'; further information on the coding of the variable is provided in the section 'Sample description and individual-level variables'. Source: Own calculations using Eurobarometer 2011 (76.1.) 
in politics and on the labour market, and public opinion might exert on citizens' support for gender boardroom quotas and on the gender gap in support. Thereafter, the data, operationalisation, and methods are described. We conclude by highlighting our main results, describing their theoretical and policy implications, and addressing limitations of our study and issues for further research.

\section{Theoretical framework}

Political institutions, structural factors, and social norms have repeatedly been shown to be relevant in explaining political attitudes besides individualistic interest-based explanations. Public policies alter the opportunity structures of citizens and thus influence their demand for governmental redistribution and intervention, as well as their political behaviour (Ferrarini 2006; Mau 2003; Svallfors 2007). Furthermore, individuals' opinions are shaped by 'exposure' to different social groups and diverging ideas (Bolzendahl and Myers 2004). Consent to state interventions to foster gender equality in economic decision-making will therefore not only be dependent on a person's individual situation and self-interest, but also on equality norms represented by the institutional and political context as well as individuals' perception of the status quo in society, whether they believe the current situation to be fair or just.

Previous research points towards an ambiguous relationship of institutions and citizens' policy preferences (Koster and Kaminska 2012). On the one hand, institutions have a norm-shaping function on public opinion: citizens' attitudes reflect the redistribution and equality principles embedded in the intuitional framework of a country (Ferrarini 2006; Svallfors 2007). Institutions therefore can influence the way citizens perceive the rights and obligations shared by members of their political community (Mau 2003). On the other hand, public opinion may also mirror dissatisfaction with the status quo and be in opposition to existing policies, functioning as a thermostat (Wlezien 1995; Soroka and Wlezien 2005). Consequently, the level of support for more governmental intervention might diminish when high levels of equality are achieved in society. Vice versa, government intervention may be accepted the more, the lower the actual level of equality in a country is.

When we transfer this dichotomy to the explanation of support of gender quotas, two contrary assumptions can be derived. In line with the argument of norm-shaping, these policies may create less opposition in societies that already have high levels of gender equality in their political, social, and economic affairs. Following the thermostat argument, in contrast, in more equal societies (further) implementation of affirmative action may create stronger opposition if citizens perceive current levels of intervention as too high and hold further measures as unnecessary. Hence, the level of support for gender quotas might be low when high levels of gender equality are achieved in society. Based on this dichotomy, we will in the following review country-level determinants of the support for gender quotas, focusing on three areas: (1) institutions and politics; (2) economic and social structure; (3) public opinion. 


\section{The general level of support for a boardroom quota}

Political institutions can influence citizens' attitudes in various ways. First, the introduction of public policies may alter the opportunity structures for citizens in terms of the incentives, possibilities and constrains they produce (Svallfors 2007). Besides affecting citizens' behaviour, public policies may also shape citizens' perceptions, orientations, and norms: the implementation of specific public policies can influence the visibility of social phenomena and can have a signalling role in pointing to the behaviours that are considered appropriate (Sjöberg 2004). Consequently, the existence of a gender quota law will have an impact on citizens' acceptance of such quotas.

As the field of politics constitutes a societal arena in which leaders and representatives are highly visible, the female representation in politics and public offices positions may further induce higher acceptance of women in leading positions in general (e.g. Kunze and Miller 2014). Moreover, it has been argued that women in politics can act as gatekeepers to push for more gender equality and better living conditions for women in society (Ferrarini 2006; Westfall and Chantiles 2016). Empirical evidence on the possible spill-over effects of political legislative gender quotas shows that beyond increasing women's formal representation, quotas have led to an increase in the gender consciousness and some forms of political activism among women (Beauregard 2017; Krook 2006).

The degree of gender equality in society and economics shapes the everyday experiences of citizens. Exposure to women at work has shown to reduce bias against female leaders among men (e.g. Finseraas et al. 2016). Moreover, nontarget group members who witness the unequal treatment of target group members are more likely to acknowledge the existence of inequality (Bolzendahl and Myers 2004), and thus, to become more supportive of policies aimed at improving equal opportunities. Therefore, high gender equality on the labour market, for example a low sectoral gender segregation, may reduce prejudice against women in leading positions, and in consequence go along with higher levels of support for quotas.

In line with the norm-shaping function of institutions, we assume that institutions, policies, and the conditions in society and economy have formative influences on citizens' attitudes, leading individuals' attitudes to conform with the normative principles embedded in institutions and promoted in society. Consequently, we expect a positive relationship between contextual factors representing gender equality and citizens' support for gender quotas.

Hypothesis 1 The higher the level of gender equality in institutions, in politics, and on the labour market, the greater will be the support for gender quotas among citizens.

A high degree of gender diversity in the labour market and an already high proportion of women in positions of leadership might also entail a lower awareness of remaining inequalities and lead to the perception that further regulations 
are unnecessary (Terjesen and Singh 2008). As a consequence, support for introducing (further) positive action might be diminished. One example for this is the discussion around the quota in Sweden where a bill by the left-wing government to introduce fines for companies that fail to accomplish a $40 \%$ female share in their executive boards was first rejected in parliament in early 2017. In a resubmission, the proposal was finally accepted in 2018 (The Guardian 2017).

Research on political quotas shows that while they indeed enhance formal equality, informal institutions and networks within parties sustain male dominance (Verge and de la Fuente 2014). Furthermore, a higher number of female representatives in political decision-making does neither necessarily increase the substantive representation of women (Celis 2009), nor follow a linear, self-reinforcing process leading to parity (Kroeber et al. 2018). Consequently, a society with high formal equality in some spheres may still embrace conservative norms and lag behind in increasing gender equality in other forms or areas. In contrast, quotas might be more welcomed by citizens in countries that in fact suffer from high inequality. This is supported by previous research that investigates impact factors of female representation on corporate boards and finds a negative relationship between a long tradition of women's political representation and women's share in company boards. Instead rather countries which are latecomers in women's political empowerment have been faster in women's business leadership representation (Terjesen and Singh 2008).

Furthermore, regulative measures as positive action may in addition cause resentment among citizens who reject state intervention in the economy. This possibly negative relationship might hold true especially for a gender quota for boardroom positions: previous research on welfare state attitudes has frequently shown that targeted measures focusing on specific groups have difficulties in achieving popularity with the general public (Kitschelt 2000; Pierson 2001). Hence, positive action benefitting a minor fraction of women should be rather unpopular. Therefore, in line with the thermostat argument, we formulate a second contrary hypothesis:

Hypothesis 2 The higher the level of gender equality in institutions, in politics, and on the labour market, the lower will be the level of support for gender quotas among citizens.

Previous research has repeatedly shown that individuals' attitudes are influenced not only by institutions and structural conditions, but also by ideology, i.e. the surrounding public opinion and values. Individuals' socialisation in a society's normative framework shapes their perceptions and attitudes towards conformity with existing social norms (Inglehart 1977). Moreover, previous research has shown that gender ideology in a country matters for women's political representation (Paxton and Kunovich 2003). For citizens' support for gender quotas in economic decision-making, two forms of attitudinal factors are relevant: norms of gender equality and the acceptance of state intervention which both will provide a favourable climate for affirmative action policies. Besides general social values, 
also political parties shape public opinion as they belong to the most prominent actors in the public and media debates. Political parties' endorsement of libertarian values and of an interventionist role of the state are likely to influence citizens' support for affirmative action policies. Therefore, we formulate the following two hypotheses:

Hypothesis 3 The more public opinion is in favour of gender equality and state intervention, the greater is the support for a gender quota.

Hypothesis 4 The more parties endorse libertarian or interventionist positions, the greater is the support for a gender quota.

\section{The gender gap in support for a boardroom quota}

Besides cross-national differences in the overall support levels for gender quotas, Fig. 1 also shows considerable variation in the gender gap of support, i.e. the difference between the mean levels of support among men and among women. Up to now, we have provided theoretical explanations for the overall level of support. However, country-level characteristics may also influence the gap in support between women and men. From a self-interest perspective, women are assumed to be generally more supportive of affirmative action policies in their favour than men. Moreover, previous research has shown that the perception of inequality against the own group is related to larger support (Tougas and Veilleux 1988). Following this argument, women as target group members might show greater sensitivity for existing gender inequalities in their society than men. The more women believe their group position in society to be disadvantaged and the less they feel their group interests to be represented in the political process, the more they will support policies enhancing their position. Therefore, we formulate the following two hypotheses on the gender gap in support:

Hypothesis 5 Women as the target group of gender quotas are more susceptible to contextual factors than men.

Hypothesis 6 The lower the institutional, political, and societal support for gender equality and the more disadvantaged the actual position of women in a country, the larger will be the gender gap in support for affirmative action policies.

\section{Data and methods}

\section{Sample description and individual-level variables}

We use the data from the Eurobarometer wave 76.1, administered in 2011 in all 27 EU member states (European Commission 2013). The sample is composed of 19,412 respondents. The dependent variable is an item measuring support for 
affirmative action policies with regard to the introduction of a gender quota for company boards. It was phrased as follows: 'Some European countries (e.g. France, Spain, the Netherlands, Italy, Belgium and Norway) have already taken legal measures to ensure a more balanced representation of men and women on company boards. Are you in favour or opposed to a legislation on this matter under the condition that qualification is taken into account without automatically favouring one of either gender?' Respondents could answer on a four-point scale ranging from 1 'totally opposed' to 4 'totally in favour'.

Across Europe exists some variation in the set-up of company boards. In most continental European countries, such as Germany, companies typically possess a two-tier leadership comprised of an executive board and a supervisory board. In these cases, quotas typically apply to the supervisory board of external non-executive directors (Kirsch 2017). In other countries, especially the Anglo-Saxon countries as well as France, one-tier corporate boards are predominant that combine the supervisory and the executive body in one board of directors (Gabaldon et al. 2017). The Eurobarometer question was adapted in each country by considering the national specificities of the set-up of company boards and by adjusting the question formulation accordingly. This adaptation of the question to the national specificities aims to ensure a functional equivalence of the measurement across countries (Harkness 2008).

Our main independent variable of interest at the individual level is gender, which is measured by a dummy for female with male as the reference category. To control for the respondents' general agreement with gender equality on company boards, we include their answer to the question 'Do you agree or disagree with the following statement: Given equal competence, women should be equally represented in positions of leadership in companies?' recoded into two categories where 0 refers to 'totally or rather opposed' and 1 refers to 'totally or rather in favour'. Other control variables at the individual level are: age (centred) and its squared term; labour force participation and its interaction with gender; left-right self-placement; educational status and its interaction with gender; level in society (self-placement); marital status; whether the respondent had children younger than 15 years old; and the level of urbanisation of the place of residence. Table 2 in "Appendix" gives an overview of the operationalisation of all individual-level variables and their means, standard deviations, minima, and maxima in the sample.

\section{Country-level variables}

We will assess the role of politics and policies with four variables. First, we use a binary variable indicating whether a country in our sample had already taken legal measures to achieve gender balance in company boards (private and public enterprises) that was binding at the latest in 2011, the year of the Eurobarometer survey; including the countries that are listed as examples in the Eurobarometer question. Information for this indicator comes from Seierstad et al. (2017), the European Commission's Network to Promote Women in Decision-making in Politics and the Economy (2011), and the Gunda Werner Institute (2016). Second, women's political 
power is operationalised with an indicator summarising information on female representation at the ministerial, parliamentary and regional assembly level in 2010. This indicator is provided by the European Institute for Gender Equality (2015) for all EU countries. The higher the value on this indicator, the higher women's political power in a country.

We operationalise gender equality in economy and society with four variables. First, we use an indicator of gender equality in economic and social life of a country as provided by the European Institute for Gender Equality (2015), with higher values indicating greater equality. The 2010 female employment rates and the 2010 sectoral gender segregation rates are used as measures for the labour market integration of women (Eurostat, 2017). The latter is approximated with women's participation rates in the sectors of craft and engineering, two traditionally male-dominated fields. Accordingly, higher values indicate lower levels of gender segregation in the labour market. Lastly, women's economic power is measured by means of the 2010 proportion of female board members in the largest quoted companies of a country (supervisory board or board of directors) (European Institute for Gender Equality 2015).

Our last group of macro-indicators concerns the measurement of public opinion and political parties' orientations. First, as indicator for the general support for gender equality in economic decision-making, we calculate for each country the proportion of respondents who agree with the item 'Given equal competence, women should be equally represented in positions of leadership in companies' as asked in the 76.1 Eurobarometer wave. Accordingly, higher values for this variable indicate greater support for gender equality in the economy. Second, as the indicator for the support for state intervention, we use the item on whether governments should reduce differences in income levels provided by the European Social Survey (ESS) 2010. We use the weighted country mean of respondents' answers on a scale from 1 'Disagree strongly' to 5 'Agree strongly'. Unfortunately, the 2010 ESS did not cover Latvia, Malta, and Romania. Furthermore, for Austria and Luxembourg we have to use information from previous ESS waves. Finally, political parties' orientations across countries are assessed by using the Chapel Hill Party dataset. This cross-national expert survey was conducted in all EU countries with the exception of Malta, Luxembourg, and Cyprus and contains items evaluating political parties' positions on the libertarian/traditional ideological dimension and on the laissezfaire/interventionist dimension (Bakker et al. 2012). The libertarian/traditional orientation item (the so-called GALTAN dimension) refers to the position of parties in terms of their views on democratic freedoms and ranges from 0 (most libertarian) to 10 (most traditional). The laissez-faire/interventionist orientation item relates to the position of political parties towards the role the state should adopt in economic issues and ranges from 0 (pro-interventionism) to 10 (pro-laissez-faire). To compute the average position of political parties in each country, we weighted these items with the percentage of votes each party obtained in the national election that took place around 2010. In this way, we used a measure of the average position on these two ideological dimensions among political parties for each country that is weighted according to the parliamentary size of each party. Table 3 in "Appendix" gives an overview of the county-specific means of all macro-level variables. 


\section{Estimation strategy}

We use multilevel regression analyses in order to account for the hierarchical structure of the data, with respondents nested in countries. The estimation of the significance of country-level indicators in multilevel models might be biased due to the rather low number of cases on the macro-level in cross-national survey data. We therefore follow the recommendations provided by Elff et al. (2016) and estimate restricted maximum likelihood models with the degrees of freedom for the country-level estimators adjusted to reflect the actual number of cases on that level. Therefore, the degrees of freedom $d f$ are calculated as

$$
d f=m-l-1
$$

with $m$ being the number of macro-level units and $l$ being the number of macro-level variables. For example, a model testing one macro-level variable and additionally controlling for GDP and existing gender quota in our dataset of 27 countries sets the number of degrees of freedom to 23 when estimating the standard errors for macrolevel variables.

Our key research interest is to identify the main effects of the country-level indicators to test Hypotheses 1-4, and their cross-level interaction effects with gender to test Hypotheses 5 and 6 . Therefore, we estimate a series of linear multilevel regression models with a random slope for gender and the macro-indicators grouped, always controlling for all individual-level variables as described above. In addition, we control for gross domestic product in purchasing power parity per capita (GDP), and whether a gender quota has already been established in a country in each model. To detect influential outliers, we calculate DFBETA values and perform repeated regressions by always leaving out one country that has DFBETA values above the cut-off value (Van der Meer et al. 2010). The results of the multilevel regression models only including the individual-level variables can be found in Table 4 in "Appendix".

\section{Results}

The intraclass correlation coefficient (ICC) amounts to 0.066 for the empty random intercept model and to 0.075 for the empty model with gender slope, which is comparable to the ICC of a previous cross-national study on the support for quota laws in politics in Latin America (Barnes and Córdova 2016). The random slope for gender is significant (variance: $0.004^{* * *}$ ), meaning that the difference between men and women in their support for a gender quota varies significantly between countries (see Table 4 in "Appendix").

Table 1 provides a summary of the results of the contextual factors and their cross-level interaction effects with gender from stepwise regression models (for full tables, see "Appendix" Table 5). Gender is highly significant in all models, indicating a gender gap in support with higher approval rates among women. In 


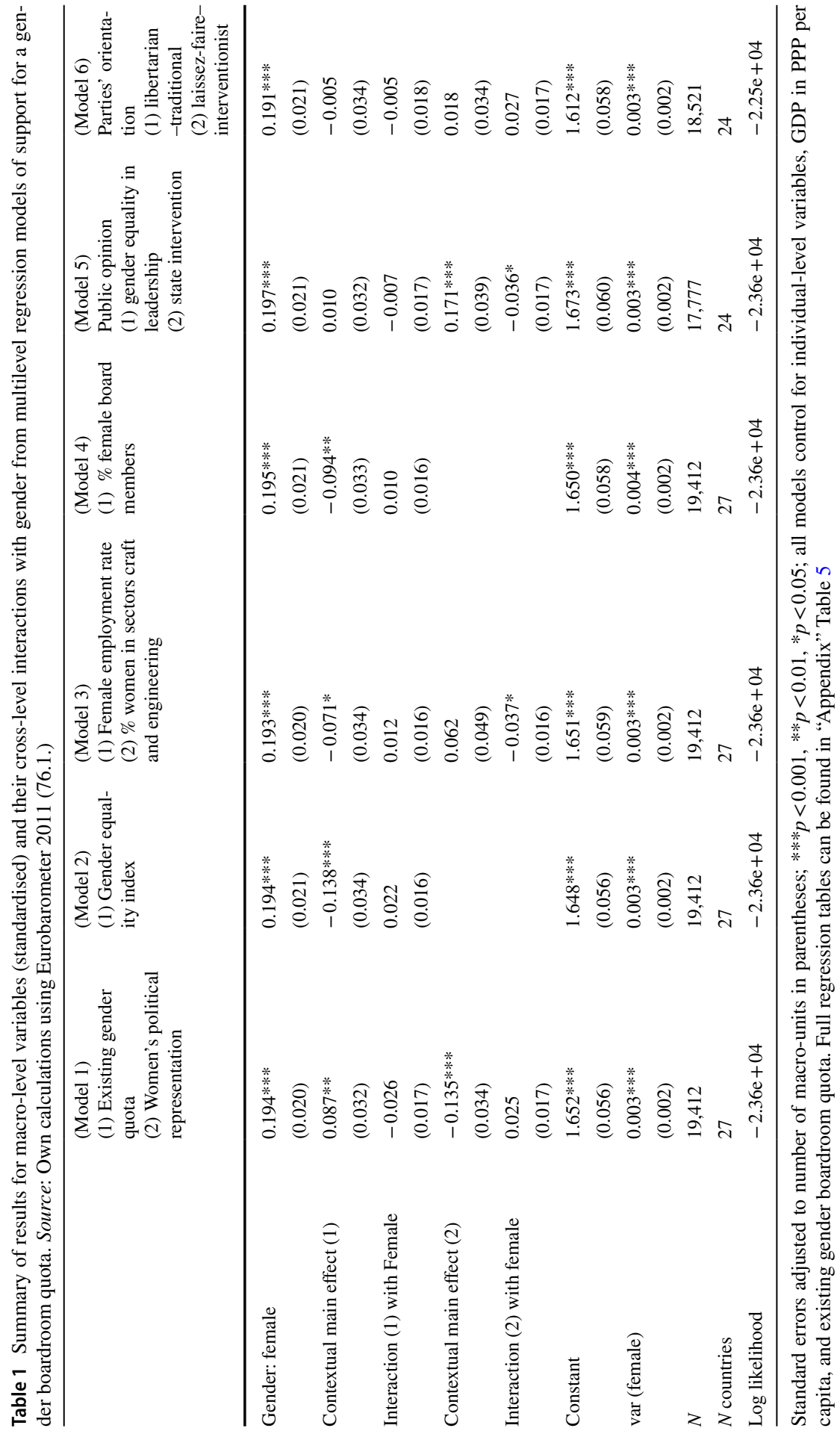

称 
the following, we will examine, in what way country-level characteristics are related to the level of and the gender gap in support for affirmative action policies.

\section{The overall level of support}

In a first step, we estimate the main effects of the macro-indicators on citizens' overall level of support for affirmative action policies. The coefficients of the main effects of the contextual factors are presented in Table 1 and Fig. 2. For the indicators representing gender equality in policies and politics, we find the following relationships. Whether a country had already implemented a gender quota in the survey year 2011 is significantly associated with citizens' support for affirmative action policies: in countries that implemented legal measures to rise the female share in company leadership before 2011, the support for boardroom quotas is higher than elsewhere (Coef.: 0.087**). However, the coefficient for existing gender quota is only significant as long as we control for women's political representation and orientations of political parties, showing that gender equality in politics and the implementation of a boardroom quota are highly related (see "Appendix" Table 5). Women's political representation shows a significant negative relation with citizens' support for affirmative action policies: the more women are represented in national and regional parliaments in a country, the lower the support for a gender quota (Coef.: $\left.-0.135^{* * *}\right)$.

The indicators representing gender equality in the economic and social life of a country also play a role for citizens' support for affirmative action policies. The gender equality index, the female employment rate, and the proportion of female board members are significantly related to citizens' attitudes towards affirmative action policies. All factors reveal a negative relationship: citizens' support for a quota is lower, the higher the overall level of gender equality (Coef.: $-0.138^{* * *}$ ), the higher the female employment rate (Coef.: $\left.-0.071^{*}\right)$, and the higher the proportion of women in boardroom positions (Coef.: $-0.094^{* *}$ ). Only labour market gender segregation (measured by the proportion of women employed in the sectors of craft and engineering) does not show a significant main effect on citizens' support for a gender boardroom quota.

With respect to public opinion, we find a significant association with citizens' support for affirmative action policies only for interventionist attitudes: the larger the overall societal support for state intervention, the higher the individual's support for affirmative action policies (Coef.: 0.171***). By contrast, the general support for gender equality in economic decision-making is not significantly related to individuals' support for gender boardroom quotas. The ideological orientations of parties also do not show to have a significant effect on citizens' support for quotas.

Interpreting these results in the light of our hypotheses leads us to distinguish between the effects of institutions and social structure. Indeed, our significant contextual indicators measuring gender equality in social life and on the labour market show a consistent negative association with citizens' support for a gender quota. In other words, the greater the formal gender equality in political representation, economic and social life in fact is, the lower the citizens' support for binding quotas. 


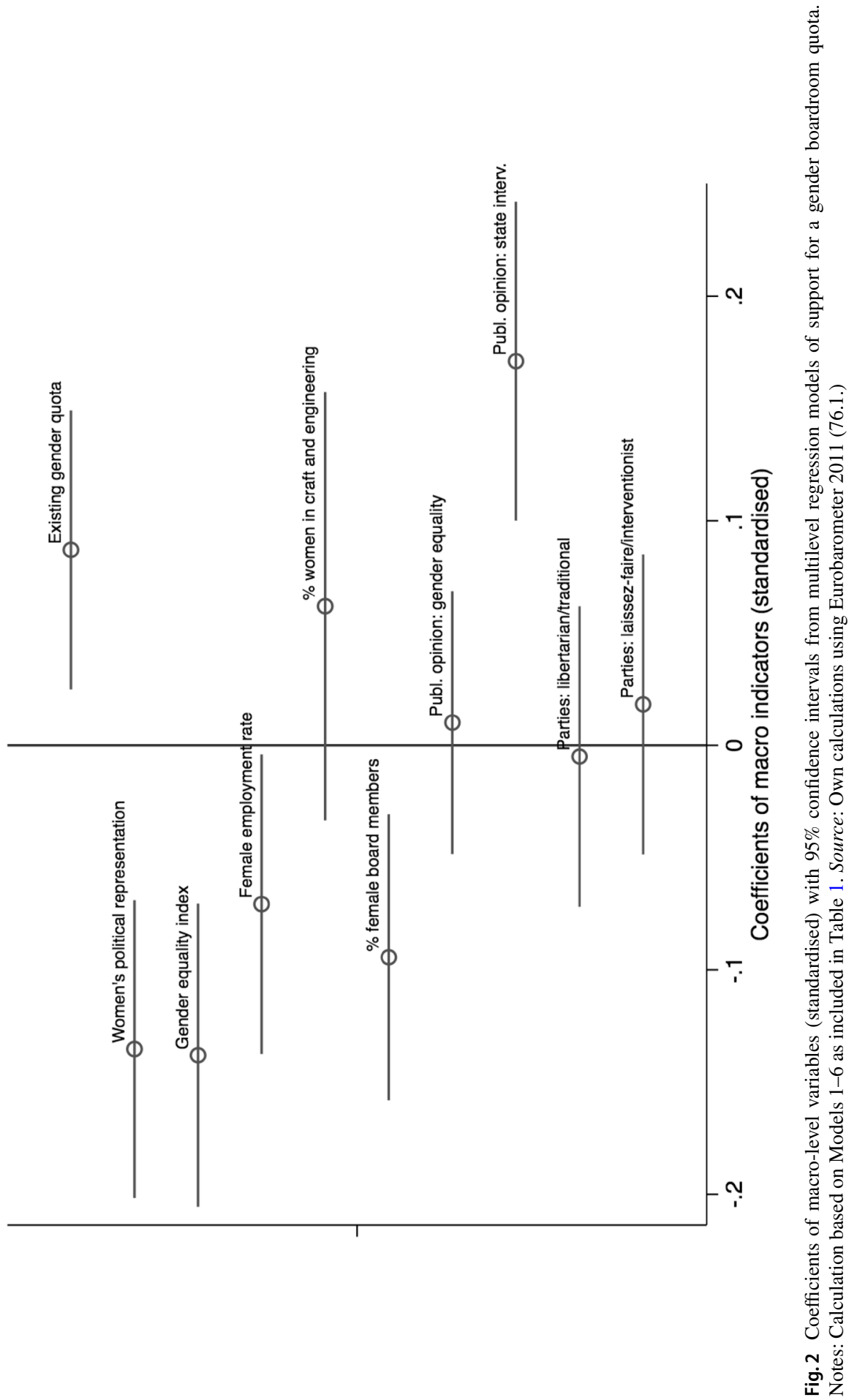

s. 
This provides support for Hypothesis 2: citizens in more egalitarian countries seem to oppose the implementation of affirmative action policies to redress gender inequality in leading positions more than citizens in less egalitarian societies. In contrast, the significant positive coefficient of existing gender quotas does confirm the assumption that existing regulations can shape individuals' attitudes towards conformity, providing some support for Hypothesis 1 . Furthermore, the significant coefficient for the indicator measuring acceptance of state intervention gives some support to Hypothesis 3: citizens are in favour of gender quotas to a larger extent in countries with higher acceptance levels of state interventionism.

\section{The gender gap in support}

In order to assess the extent to which target and non-target group members are affected differently by contextual factors, we test their interaction effects with gender (coded as female, with male being the reference category) in the second step of our analysis (see Table 1). We find significant interaction effects only for the sectoral gender segregation and the societal support for state intervention. The marginal effects of these significant cross-level interactions for different values of the contextual indicators are presented in Fig. 3. Both indicators are negatively related to the gender gap in support: the higher the share of women working in craft and engineering and the higher the general support for state interventionism in a country,
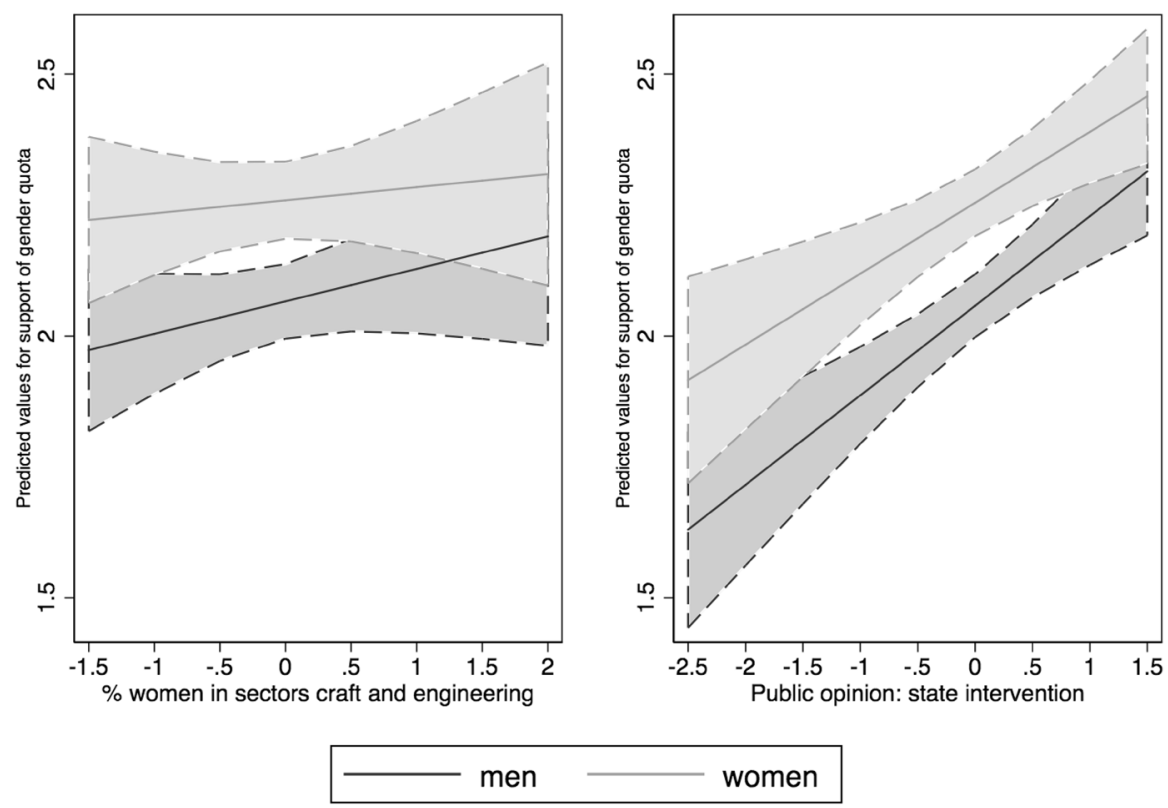

Fig. 3 Marginal effects for the cross-level interactions from multilevel regression models of support for a gender boardroom quota. Notes: Calculation based on Models 3 and 5 as included in Table 1. Source: Own calculations using Eurobarometer 2011 (76.1.) 
the smaller the difference between men and women in their support for affirmative action policies. This smaller gender gap is due to men's support for quotas being more affected by the level of support for state intervention and sectoral gender segregation.

If we interpret these results in the light of our last two hypotheses, we find only very weak support for Hypothesis 6 and need to reject Hypothesis 5. Indeed, we assumed that women as the target group of affirmative action policies would be more sensitive to contextual factors (Hypothesis 5). However, the fact that almost all cross-level interaction effects are insignificant does not confirm this assumption; rather, men and women within a country mostly seem to be similarly influenced by the contextual factors we considered in this study. Furthermore, the significant cross-level interaction effects plotted in Fig. 3 show that men's support is affected to a slightly greater extent by the sectoral gender segregation and the societal support for state interventionism. Thus, these two contextual factors play a larger role in the support for affirmative action policies expressed by members of the non-target group as opposed to that of the target group. Finally, our last hypothesis stated that the more disadvantaged the actual position of women in a country, the larger will be the gender gap in support for affirmative action policies (Hypothesis 6). Only the significant cross-level interaction effect on sectoral gender segregation provides some evidence for this hypothesis: differences between men's and women's support for affirmative action policies are significantly lower in countries with a higher proportion of women working in craft and engineering.

\section{Robustness analysis}

According to the DFBETA values of our first range of regression models, ten countries are potentially influential outliers for significant macro-indicators (results not depicted). To further test the robustness of the results of the contextual indicators, we estimate repeated regression models by always leaving out one of these countries. The results of these estimations show that the coefficient for the proportion of female directors is driven only by Sweden, which had the third highest proportion of women on company boards in the sample in 2010. Leaving out Sweden, the coefficient is still negative, but becomes insignificant on a 0.050 level ( $p$-value of 0.092 as compared to 0.021 before).

\section{Conclusion}

A fine-grained understanding of citizens' attitudes towards group-based policies that aim to redress inequality is essential for the assessment of the challenges facing the implementation of such policies. Large differences between countries do not only exist in the proportion of women in such leading positions, but also in citizens' levels of support for gender boardroom quotas and the gap in support between men and women. Gender quotas for company boards have been and still are a widely disputed topic in many European countries. Assessing the role of contextual factors can 
help to understand the sources of these cross-national differences, which might be of particular importance to policy makers and interest groups aiming to push forward gender equality.

Our results show the significant role of contextual factors related to the actual level of gender equality and position of women in society to explain overall levels of support for gender quotas. Those who belong to the target group of the policywomen-are significantly more supportive of affirmative action policies than nontarget group members-men-in all countries. However, both groups seem to adjust their opinion to the actual conditions in a country. Hence, the relevance of groupbased interest in the support for affirmative action policies is context-dependent.

Generally, contextual factors related to the actual social and labour market structure play a pivotal role in citizens' support for affirmative action policies. Furthermore, political institutions also show to be relevant. The institutionalisation of equality norms in legislation, i.e. the implementation of quota laws, is positively related to citizens' acceptance of these laws. This result is in line with previous research showing a positive impact of political quotas on women's political activism (Beauregard 2017); however, we cannot establish a causal relationship based on our cross-sectional data. By contrast, the higher the actual level of gender equality in a society, the higher the female employment rate, and the more equal representation of women in politics and leading business positions, the lower is citizens' support for a gender quota for company boards. The support for affirmative action policies thus seems to reflect adverse conditions in a country: approval of a gender quota among both men and women is high where gender equality in the labour market and in leading positions is low. By contrast, affirmative action policies are supported less in countries where formal gender equality in the economy and in political representation is already at a high level. These findings provide some indication for a backlash: the higher the level of gender equality in a country, the lower is citizens' support for further interventionist policies aiming at redressing gender inequality. Respondents in highly gender-equal countries might be more likely to believe that remaining gender gaps are due to women's preferences and individual merit rather than to systematic gender discrimination. Such a belief would in turn lead to reject further state intervention in this matter. The national framing surrounding the causes of the gender gap in company boards is indeed assumed to affect the extent of a country's intervention in implementing a gender quota (Piscopo and Muntean 2018). Similarly, the causal frames with which respondents evaluate the necessity of a gender quota is very likely to be a key determinant in their support for it. Unfortunately, the available items in the Eurobarometer data did not allow us to take into account such causal frames in our analyses.

A further interesting finding of our study concerns the fact that support for affirmative action policies towards women and general gender equality norms represent two distinct attitudinal dimensions. The overall societal level of support for gender equality in economic decision-making is not significantly related to the approval of a gender quota. By contrast, societal support for state interventionism plays a significant role in citizens' preferences for affirmative action policies: the higher the societal support for state interventionism, the higher citizens' approval of the implementation of gender quotas for company boards. Hence, binding quota 
regulations may lack a broad public support not because of an underlying opposition to gender equality, but due to the interventionist character of such policies. Indeed, national discursive frames regarding gender quotas for company boards might play a crucial role in citizens' support for such quotas. Previous studies pointed to large country differences in the national discursive frames surrounding persistent gender gap and inequality (Piscopo and Muntean 2018) as well as in the state responsibility to redress it (Teigen and Wängnerud 2009). These distinct national framings are likely, in turn, to affect the ideological frames with which individuals interpret regulations and policies such as the implementation of binding gender quotas in company boards. For example, the strong opposition to gender quotas in Denmark might be related to the belief that gender equality has already by and large been achieved, therefore is a 'closed case', as identified by Dahlerup (2018) among a large minority of conservative MPs in the Danish parliament. Disentangling the ideological frames behind support for gender quotas at the individual level and relating it with the respective national frames in all EU countries is beyond the scope of this article. It constitutes, however, a promising research avenue if we want to better understand support for policies that are related to distinct ideological dimensions, such as the implementation of gender quotas.

Lastly, our results showed that the association between societal support for state interventionism and preferences for a gender quota is stronger for the non-target group members-men-than for the target group members-women. Moreover, men living in countries with less gender segregation in the labour market support gender quotas to a larger extent, while the sectoral gender segregation is less relevant for women's attitudes towards gender quotas. This supports the 'exposure' argument that contact between target and non-target group members has a positive impact on the attitudes on non-target group members.

To the best of our knowledge, this study is the first to investigate the role of contextual factors in shaping support for affirmative action policies in the economy in the European context. As a pioneering study, it also suffers from several limitations, which will hopefully be tackled in future research. For instance, we use data from a survey in 2011 as there is unfortunately no newer data source available. While the public discussion on gender quotas was already ongoing in this year, quota laws had been established in few European countries very recently at that time. Given the changes in quota laws over the last few years, a new data collection on this topic would be helpful to assess reactions to these more recent changes. Also, as there is no other survey available on this question, we were bound to the question wording as used by Eurobarometer that included names of specific countries in the question text. If a respondent dislikes specifically one or few of these named countries that may have shaped their answer. We, however, include country dummies for the countries named in the questions text in all regression models.

In addition, previous country studies highlighted the relevance of national path dependency (Teigen 2012), the national structure and culture of politics and the economy (Chandler 2016; Magnier and Rosenblum 2014), national gender equality 
cultures (Teigen and Wängnerud 2009) as well as the national framing on boardroom quotas for women (Piscopo and Muntean 2018) for understanding country disparities in gender quotas in company boards. The adoption of a large-N study design implies the use of standardised and aggregated indicators across countries. We were therefore unable to consider these various country particularities in our analyses, which are nevertheless very likely to be important factors in citizens' support for gender quotas.

Furthermore, we made the assumption that the contextual factors shape public opinion on affirmative action policies. However, citizens' attitudes are also likely to influence the implementation of policies, political parties' ideological orientations, and the extent to which underrepresented groups manage to hold visible leading positions in various societal arenas. The cross-sectional structure of the data we used for this study did not allow us to assess these feedback loops in more detail. Moreover, our analysis focuses on support for affirmative action policies for a specific underrepresented group (women) in a specific societal arena (leading business positions). Future research which includes a larger set of attitudinal measurements could shed light on the generalisability of our findings to other underrepresented groups and societal arenas.

Acknowledgements We thank the participants of the Paper Workshop at the SOCIUM, University of Bremen, the participants of the Paper Workshop at the Collaborative Research Center SFB 884, University of Mannheim, and the participants of the Visiting Scholars Seminar at the Center for European Studies, Harvard University, for their helpful comments.

Funding This research was partly funded by the institutional strategy of the University of Bremen within the excellence funding of the German federal government and federal states allocated to the second author, and by the Deutsche Forschungsgemeinschaft, Collaborative Research Center SFB 884 'Political Economy of Reforms', allocated to the first author.

Open Access This article is distributed under the terms of the Creative Commons Attribution 4.0 International License (http://creativecommons.org/licenses/by/4.0/), which permits unrestricted use, distribution, and reproduction in any medium, provided you give appropriate credit to the original author(s) and the source, provide a link to the Creative Commons license, and indicate if changes were made.

\section{Appendix}

See Tables 2, 3, 4, and 5 . 


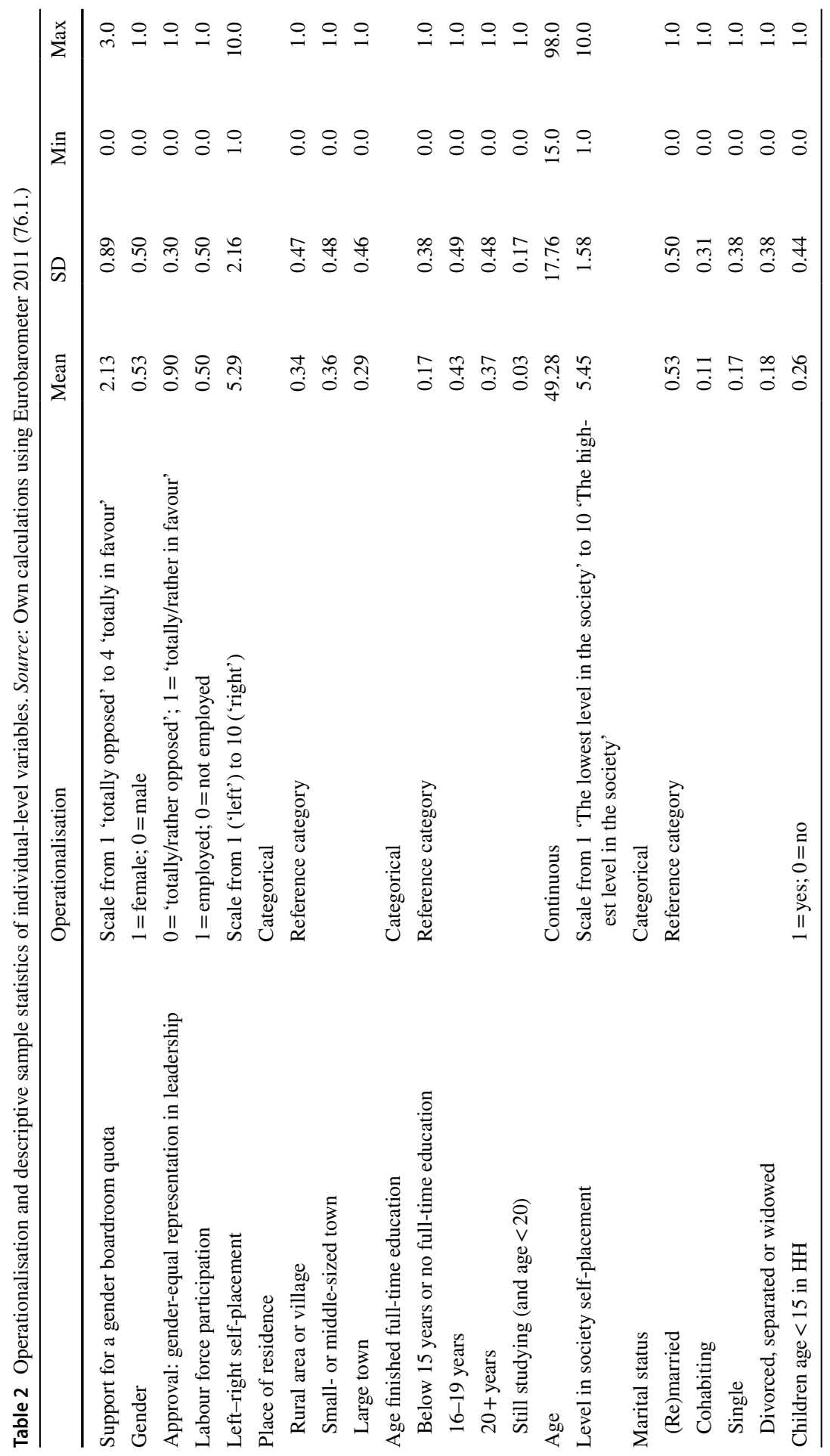




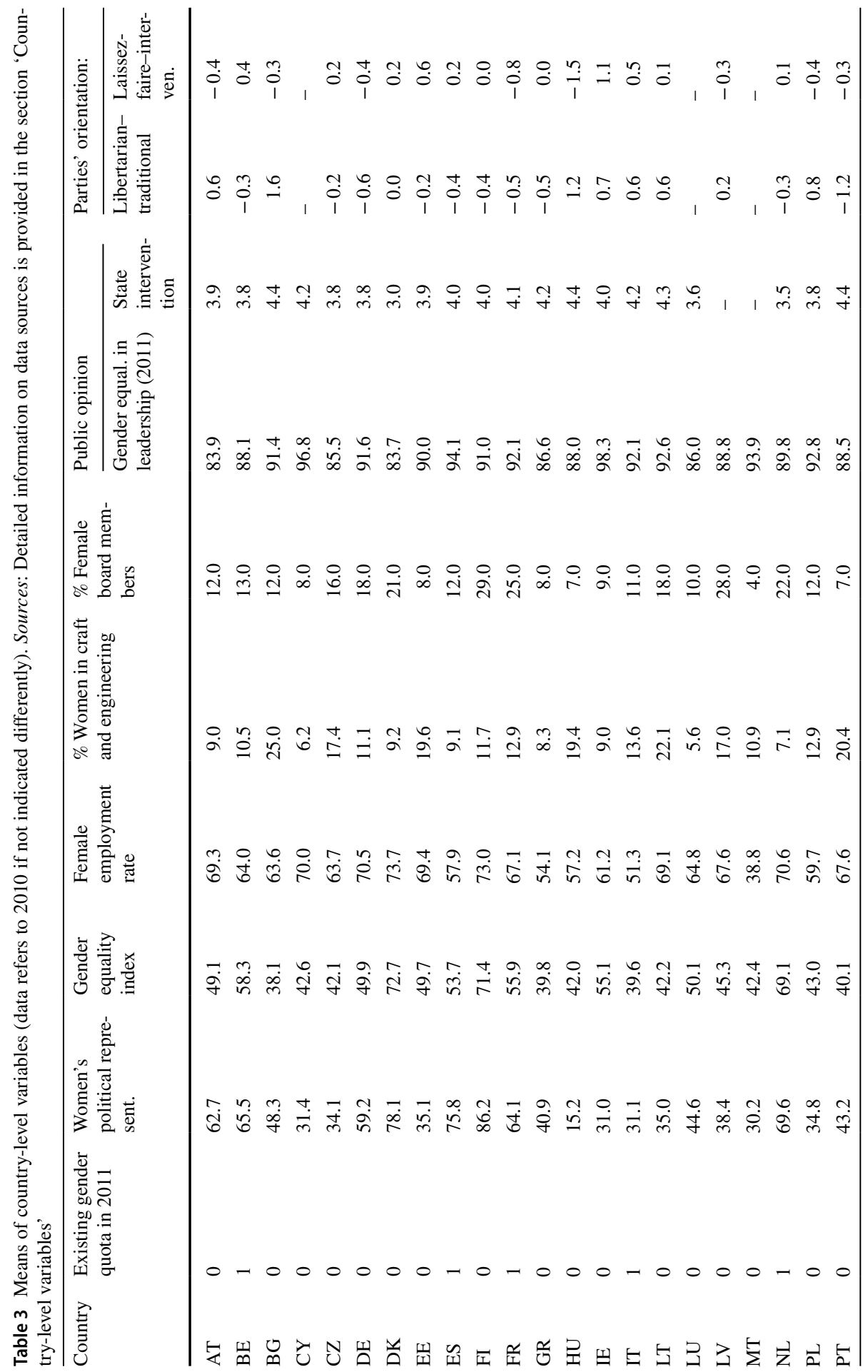


580

K. Möhring, C. Teney

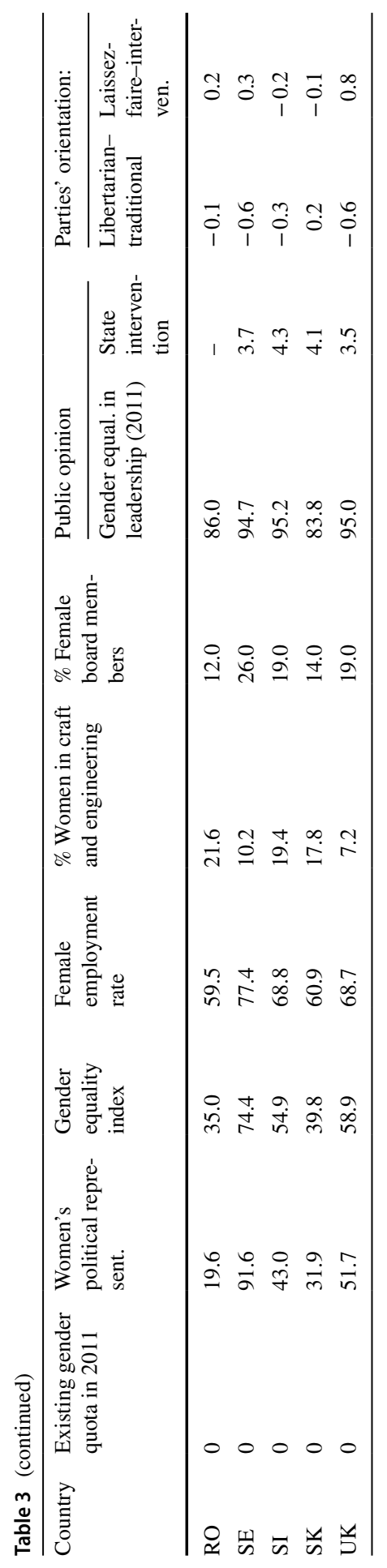


Table 4 Multilevel regression models of support for a gender boardroom quota, individual-level variables. Source: Own calculations using Eurobarometer 2011 (76.1.)

\begin{tabular}{|c|c|c|}
\hline & Random intercept model & Random slope model \\
\hline Gender: female & $\begin{array}{l}0.195 * * * \\
(0.017)\end{array}$ & $\begin{array}{l}0.195 * * * \\
(0.021)\end{array}$ \\
\hline Approval: gender-equal representation in leadership & $\begin{array}{l}0.770 * * * \\
(0.020)\end{array}$ & $\begin{array}{l}0.768 * * * \\
(0.020)\end{array}$ \\
\hline Employed (RC: not employed) & $\begin{array}{l}-0.089 * * * \\
(0.019)\end{array}$ & $\begin{array}{l}-0.088^{* * * *} \\
(0.019)\end{array}$ \\
\hline Female $\times$ employed & $\begin{array}{l}0.088 * * * \\
(0.024)\end{array}$ & $\begin{array}{l}0.086 * * * \\
(0.024)\end{array}$ \\
\hline \multicolumn{3}{|l|}{$\begin{array}{l}\text { Age finished full-time education } \\
\text { (RC: below } 15 \text { years or no education) }\end{array}$} \\
\hline $16-19$ years & $\begin{array}{l}0.047 * \\
(0.018)\end{array}$ & $\begin{array}{l}0.047 * \\
(0.018)\end{array}$ \\
\hline $20+$ years & $\begin{array}{l}-0.014 \\
(0.020)\end{array}$ & $\begin{array}{l}-0.014 \\
(0.020)\end{array}$ \\
\hline Still Studying & $\begin{array}{l}0.036 \\
(0.042)\end{array}$ & $\begin{array}{l}0.036 \\
(0.042)\end{array}$ \\
\hline Age & $\begin{array}{l}-0.002^{* * * *} \\
(0.000)\end{array}$ & $\begin{array}{l}-0.002^{* * * *} \\
(0.000)\end{array}$ \\
\hline Level in society (self-placement) & $\begin{array}{l}-0.016^{* * * *} \\
(0.004)\end{array}$ & $\begin{array}{l}-0.016^{* * * *} \\
(0.004)\end{array}$ \\
\hline Left-right self-placement & $\begin{array}{l}-0.019 * * * \\
(0.003)\end{array}$ & $\begin{array}{l}-0.019 * * * \\
(0.003)\end{array}$ \\
\hline \multicolumn{3}{|l|}{ Place of residence (RC: rural area or village) } \\
\hline Small- or middle-sized town & $\begin{array}{l}-0.002 \\
(0.014)\end{array}$ & $\begin{array}{l}-0.002 \\
(0.014)\end{array}$ \\
\hline Large town & $\begin{array}{l}-0.006 \\
(0.015)\end{array}$ & $\begin{array}{l}-0.007 \\
(0.015)\end{array}$ \\
\hline \multicolumn{3}{|l|}{ Marital status [RC: (Re)married] } \\
\hline Cohabiting & $\begin{array}{l}-0.021 \\
(0.021)\end{array}$ & $\begin{array}{l}-0.021 \\
(0.021)\end{array}$ \\
\hline Single & $\begin{array}{l}0.041 * \\
(0.019)\end{array}$ & $\begin{array}{l}0.041 * \\
(0.019)\end{array}$ \\
\hline Divorced, separated, or widowed & $\begin{array}{l}-0.008 \\
(0.017)\end{array}$ & $\begin{array}{l}-0.008 \\
(0.017)\end{array}$ \\
\hline Children age $<15$ in $\mathrm{HH}$ & $\begin{array}{l}0.001 \\
(0.015)\end{array}$ & $\begin{array}{l}0.002 \\
(0.015)\end{array}$ \\
\hline Constant & $\begin{array}{l}1.658 * * * \\
(0.061)\end{array}$ & $\begin{array}{l}1.655 * * * \\
(0.062)\end{array}$ \\
\hline var(Gender: Female) & & $\begin{array}{l}0.004 * * * \\
(0.002)\end{array}$ \\
\hline $\operatorname{var}($ Constant $)$ & $\begin{array}{l}0.038 * * * \\
(0.011)\end{array}$ & $\begin{array}{l}0.042 * * * \\
(0.012)\end{array}$ \\
\hline
\end{tabular}


Table 4 (continued)

\begin{tabular}{lll}
\hline & Random intercept model & Random slope model \\
\hline var(Residual) & $0.661^{* * *}$ & $0.660^{* * *}$ \\
& $(0.007)$ & $(0.007)$ \\
$N$ & 19,412 & 19,412 \\
Wald chi sq. & 2323.233 & 1986.350 \\
Log likelihood & $-2.36 \mathrm{e}+04$ & $-2.36 \mathrm{e}+04$ \\
\hline
\end{tabular}

Standard error in parentheses; $* * * p<0.001,{ }^{* *} p<0.01,{ }^{*} p<0.05,+p<0.1$ 


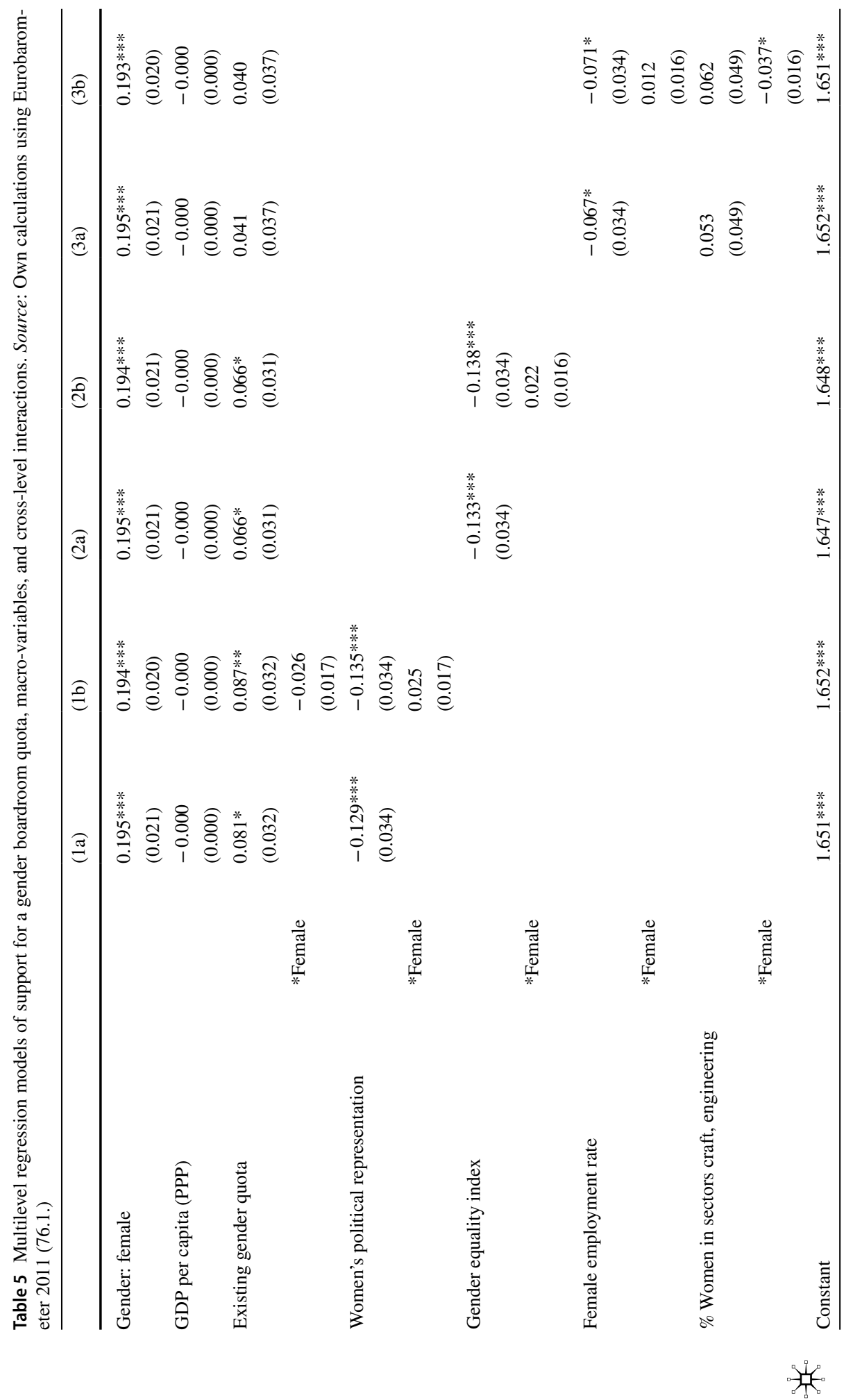




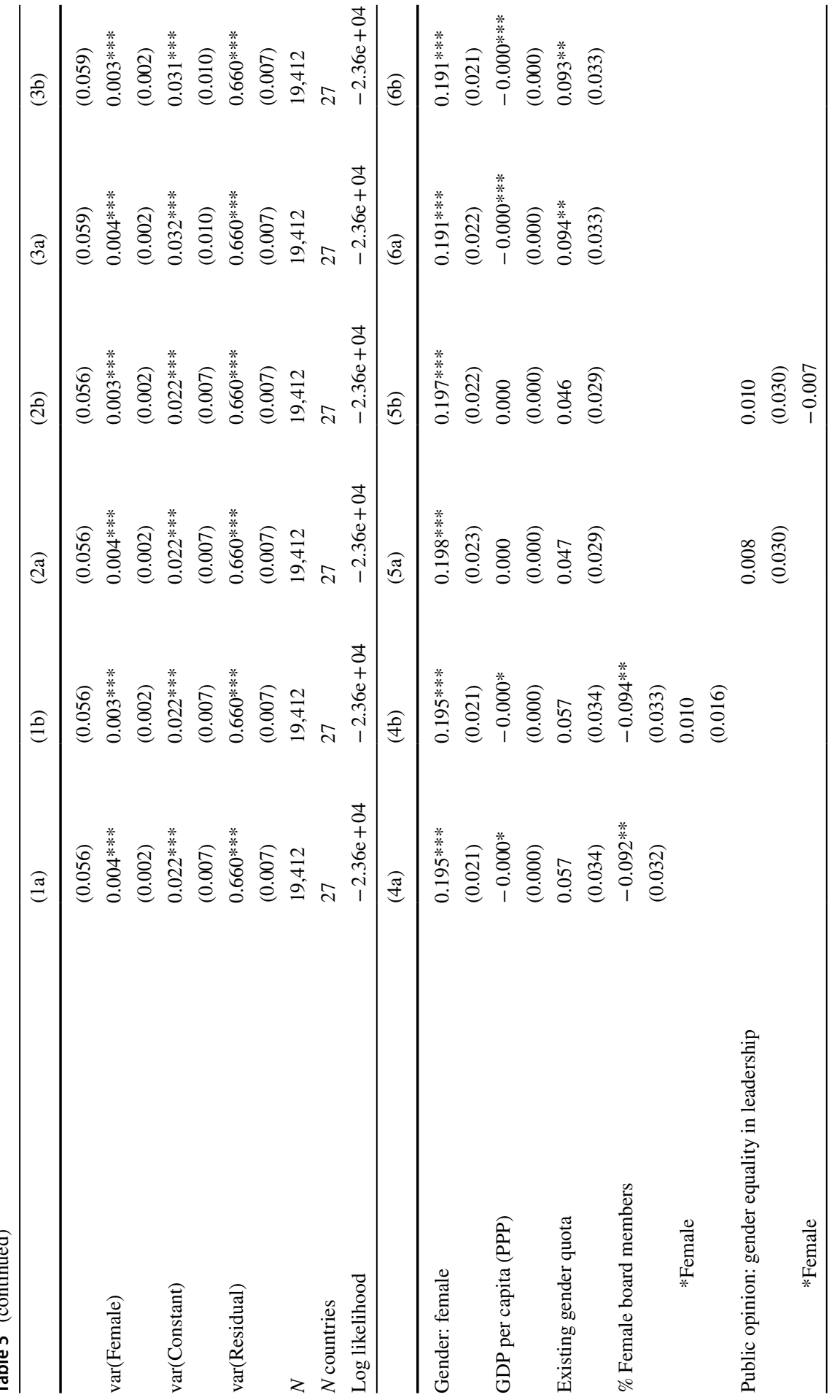

年 


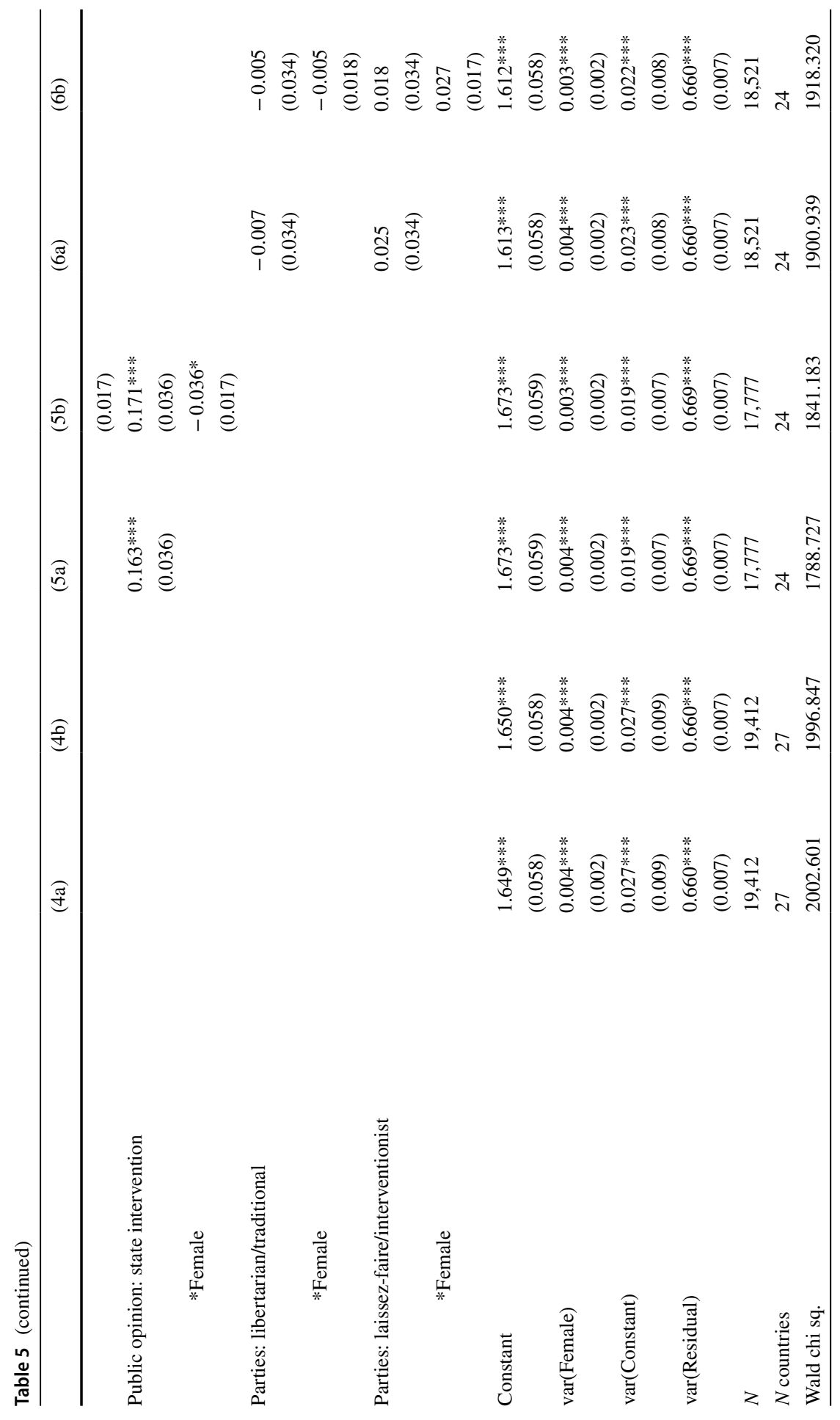




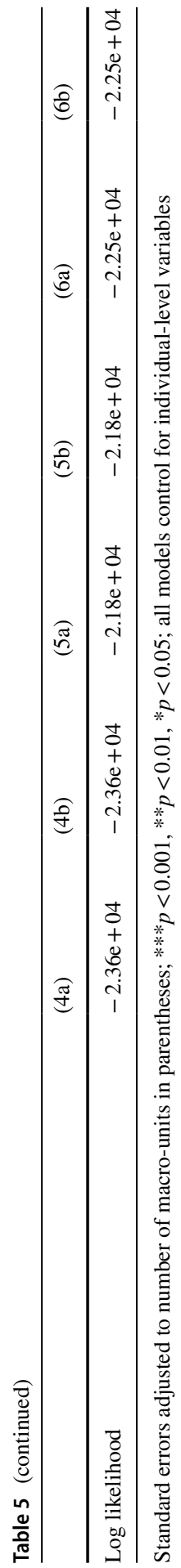

站。 


\section{References}

Armstrong, J., and S. Walby. 2012. Gender Quotas in Management Boards. Brussels: European Parliament's Committee on Gender Equality.

Bakker, R., C. de Vries, E. Edwards, L. Hooghe, S. Jolly, G. Marks, and M.A. Vachudova. 2012. Measuring Party Positions in Europe: The Chapel Hill Expert Survey Trend File, 1999-2010. Party Politics 21: $143-152$.

Barnes, T., and A. Córdova. 2016. Making Space for Women: Explaining Citizen Support for Legislative Gender Quotas in Latin America. Journal of Politics 78 (3): 670-686.

Beauregard, K. 2017. Quotas and Gender Gaps in Political Participation among Established Industrial European Democracies: Distinguishing Within- and Across-Country Effects. Political Research Quarterly 70 (3): 657-672.

Bolzendahl, C.I., and D.J. Myers. 2004. Feminist Attitudes and Support for Gender Equality: Opinion Change in Women and Men, 1974-1998. Social Forces 83: 759-789.

Celis, K. 2009. Substantive Representation of Women (and Improving it): What it is and should be About? Comparative European Politics 7 (1): 95-113.

Chandler, A. 2016. Women on Corporate Boards: A Comparison of Parliamentary Discourse in the United Kingdom and France. Politics \& Gender 12 (3): 443-468.

Chaperon, I. 2015. En Entreprise, les Cercles du Puvoir se Féminisent. Le Monde. http://www.lemon de.fr/economie/article/2015/03/07/en-entreprise-les-cercles-du-pouvoir-se-feminisent_45892 42_3234.html?xtmc=femme_quota_pdg\&xtcr=2. Accessed 7 March 2015.

Dahlerup, D. 2018. Gender Equality as a Closed Case: A Survey among the Members of the 2015 Danish Parliament. Scandinavian Political Studies 41 (2): 188-209.

Elff, M., J. P. Heisig, M. Schaeffer, \& S. Shikano 2016. No Need to Turn Bayesian in Multilevel Analysis with Few Clusters: How Frequentist Methods Provide Unbiased Estimates and Accurate Inference. https://doi.org/10.31235/osf.io/z65s4. Accessed 28 August 2018.

Elomäki, A. 2017. Gender Quotas for Corporate Boards: Depoliticizing Gender and the Economy. NORA-Nordic Journal of Feminist and Gender Research 26 (1): 53-68.

European Commission, and European Parliament. 2013. Eurobarometer 76.1: Financial and Economic Crisis, Financial Services, Corruption, Development Aid, and Gender Equality, September 2011. Ann Arbor, MI: Inter-university Consortium for Political and Social Research [distributor]. https://doi.org/10.3886/ICPSR34552.v2. Accessed 11 October 2013.

European Commission. 2016. Factsheet Gender Balance on Corporate Boards. http://ec.europa.eu/ justice/gender-equality/files/gender_balance_decision_making/1607_factsheet_final_wob_data_ en.pdf. Accessed 22 November 2017.

European Commission's Network to Promote Women in Decision-making in Politics and the Economy. (2011) The Quota-instrument: Different Approaches across Europe. http://ec.europa.eu/ justice/gender-equality/files/quota-working_paper_en.pdf. Accessed 22 November 2017.

European Institute for Gender Equality. 2015. Gender Equality Index 2015. Measuring Gender Equality in the European Union 2005-2012. http://eige.europa.eu/gender-statistics/gender-equalityindex. Accessed 22 November 2017.

Eurostat. 2017. Employment rates by sex, age and citizenship (\%) [lfsq_ergan]. http://appsso.eurostat. ec.europa.eu/nui/show.do?dataset=lfsq_ergan\&lang=en. Accessed 22 November 2017.

Ferrarini, T. 2006. Families, States and Labour Markets. Institutions, Causes and Consequences of Family Policy in Post-War Welfare States. Cheltenham: Edward Elgar.

Finseraas, H., Å.A. Johnsen, A. Kotsadam, and G. Torsvik. 2016. Exposure to Female Colleagues Breaks the Glass Ceiling-Evidence from a Combined Vignette and Field Experiment. European Economic Review 90: 363-374.

Gabaldon, P., H. Mensi-Klarbach, and C. Seierstad. 2017. Gender Diversity in the Boardroom: The Multiple Versions of Quota Laws in Europe. In Gender Diversity in the Boardroom, ed. C. Seierstad, P. Gabaldon, and H. Mensi-Klarbach, 233-254. Cham: Springer.

Gunda Werner Institute. 2016. Feminism and Gender Democracy, EU Countries Comparison. http:// www.gwi-boell.de/en/topics/europe/eu-countries-comparison. Accessed 22 November 2017.

Harkness, J.A. 2008. Comparative Survey Research: Goal and Challenges. In International Handbook of Survey Methodology, ed. E. de Leeuw, J. Hox, and D.A. Dillman, 56-77. New York: Psychology Press. 
Harrison, D.A., D.A. Kravitz, D.M. Mayer, L.M. Leslie, and D. Lev-Arey. 2006. Understanding Attitudes Toward Affirmative Action Programs in Employment: Summary and Meta-Analysis of 35 Years of Research. Journal of Applied Psychology 91: 1013-1036.

Inglehart, R. 1977. The Silent Revolution. Changing Values and Political Styles Among Western Publics. Princeton, NJ: Princeton University Press.

Kirsch, A. 2017. Women's Access to Boards in Germany-Regulation and Symbolic Change. In Gender Diversity in the Boardroom, ed. C. Seierstad, P. Gabaldon, and H. Mensi-Klarbach, 205-232. Cham: Springer International Publishing.

Kitschelt, H. 2000. Linkages Between Citizens and Politicians in Democratic Polities. Comparative Political Studies 33: 845-879.

Kroeber, C., V. Marent, J. Fortin-Rittberger, and C. Eder. 2018. Still a glass ceiling? Tracing the limits to women's representation in elected office. Comparative European Politics, Online First.

Koster, F., and M.-E. Kaminska. 2012. Welfare state values in the European Union, 2002-2008. A multilevel investigation of formal institutions and individual attitudes. Journal of European Public Policy 19 (6): 900-920.

Kováts, E. 2018. Conservative Counter-Movements? Overcoming Culturalising Interpretations of RightWing Mobilizations Against "Gender Ideology". Femina Politica. Zeitschrift Für Feministische Politikwissenschaft 2018 (1): 75-88.

Krook, M.L. 2006. Gender Quotas, Norms, and Politics. Politics \& Gender 2 (1): 110-118.

Krysan, M. 2000. Prejudice, Politics, and Public Opinion: Understanding the Sources of Racial Policy Attitudes. Annual Review of Sociology 26: 135-168.

Kunze, A., and A.R. Miller. 2014. 'Women Helping Women? Evidence from Private Sector Data on Workplace Hierarchies, National Bureau of Economic Research'. NBER Working Paper No. 20761. Cambridge, MA: National Bureau of Economic Research. http://www.nber.org/papers/w20761. Accessed 1 November 2017.

Mau, S. 2003. The Moral Economy of Welfare States. Britain and Germany Compared, London: Routledge.

Magnier, V., and D. Rosenblum. 2014. Quotas and the Transatlantic Divergence of Corporate Governance. Northwestern Journal of International Law and Business 34: 249-298.

Paxton, P., and S. Kunovich. 2003. Women's Political Representation: The Importance of Ideology. Social Forces 82: 87-114.

Pierson, P. 2001. The New Politics of the Welfare State. Oxford: Oxford University Press.

Piscopo, J.M., and S.C. Muntean. 2018. Corporate Quotas and Symbolic Politics in Advanced Democracies. Journal of Women. Politics \& Policy 39 (3): 285-309.

Pollack, M.A., and E. Hafner-Burton. 2000. Mainstreaming gender in the European Union. Journal of European Public Policy 7 (3): 432-456.

Ruedin, D. 2012. The Representation of Women in National Parliaments: A Cross-national Comparison. European Sociological Review 28: 96-109.

Seierstad, C., P. Gabaldon, and H. Mensi-Klarbach (eds.). 2017. Gender Diversity in the Boardroom. Cham: Springer International Publishing.

Sjöberg, O. 2004. The Role of Family Policy Institutions in Explaining Gender-Role Attitudes: A Comparative Multilevel Analysis of Thirteen Industrialized Countries. Journal of European Social Policy 14: 107-123.

Soroka, S.N., and C. Wlezien. 2005. Opinion-Policy Dynamics: Public Preferences and Public Expenditure in the United Kingdom. British Journal of Political Science 35 (4): 665-689.

Svallfors, S. 2007. 'Introduction', In The Political Sociology of the Welfare State. Institutions, Social Cleavages, and Orientations, ed. S. Svallfors, 1-29. Stanford: Stanford University Press.

Teigen, M. 2012. Gender Quotas onn Corporate Boards: On the Diffusion of a Distinct National Policy Reform. In Firms, Boards and Gender Quotas: Comparative Perspective, ed. F. Engelstad and M. Teigen, 115-146. Bingley: Emerald Group Publishing Limited.

Teigen, M., and L. Wängnerud. 2009. Tracing Gender Equality Cultures: Elite Perceptions of Gender Equality in Norway and Sweden. Politics \& Gender 5: 21-44.

Terjesen, S., and V. Singh. 2008. Female Presence on Corporate Boards: A Multi-Country Study of Environmental Context. Journal of Business Ethics 83 (1): 55-63.

The Guardian. 2017. Sweden rejects quotas for women on boards of listed companies. https://www. theguardian.com/world/2017/jan/12/sweden-rejects-quotas-women-boardroom-listed-companies. Accessed 12 January 2018. 
Tougas, F., and F. Veilleux. 1988. 'The Influence of Identification, Collective Relative Deprivation, and Procedure of Implementation on Women's Response to Affirmative Action: A Causal Modeling Approach’. Canadian Journal of Behavioural Science 20 (1): 15-28.

Van der Meer, T., M. Te Grotenhuis, and B. Pelzer. 2010. Influential Cases in Multilevel Modeling: A Methodological Comment. American Sociological Review 75: 173-178.

Verge, T., and M. de la Fuente. 2014. Playing with different cards: Party politics, gender quotas and women's empowerment. International Political Science Review 35 (1): 67-79.

Weeks, A. C. 2018. Why Are Gender Quota Laws Adopted by Men? The Role of Inter- and Intraparty Competition. Comparative Political Studies, online first.

Westfall, A., and C. Chantiles. 2016. The Political Cure: Gender Quotas and Women's Health. Politics \& Gender 12 (3): 469-490.

Wlezien, C. 1995. The Public as Thermostat: Dynamics of Preferences for Spending. American Journal of Political Science 39: 981-1000.

Publisher's Note Springer Nature remains neutral with regard to jurisdictional claims in published maps and institutional affiliations.

Katja Möhring is assistant professor for Sociology of the Welfare State and currently interim professor for Macrosociology at the University of Mannheim. She completed her PhD thesis in 2013 at the University of Cologne and worked as a postdoctoral researcher at the University of Bremen. She leads projects at the Collaborative Research Center SFB 884 'Political Economy of Reforms' and the Mannheim Centre for European Social Research (MZES). Her work focuses on life courses, welfare states, gender equality, and quantitative methodology.

Céline Teney is professor for 'Fundamentals of Social Sciences' at University of Göttingen. Before, she was head of a junior research group 'Winners of Globalization? A Study on the Emergence of a Transnational Elite in Europe' at the University of Bremen. She completed her PhD thesis in 2009 at the Université libre de Bruxelles and worked as a senior researcher at the Berlin Social Science Center. Her research interests encompass political sociology, immigration, the European Union, and quantitative methodology. 